\title{
Why Fix something that is not Broken? The Implementation of School Choice Policy and Parental Attitudes towards Equality and Uniformity of Comprehensive School System in Finland
}

\author{
By Heikki Silvennoinen * \\ Mira Kalalahti ${ }^{\dagger}$ \\ Janne Varjo
}

In Finland, the pupil bodies of schools consisting of children living in the nearby area (school district) has been a central principle ever since the founding of the 'folk school' network in the 1890s. Children were allocated to schools on the basis of residence. This policy was changed in the mid 1990's and the free school choice was introduced in Finland. Although a major change in the school policy the opening of the school choice was not much discussed in the public or in the parliament. It was introduced by a promise to give parents more freedom, to better respond to the needs of the talented pupils, and to bring forth more high quality schools. The evaluation of possible unintended consequences on equality was neglected. In this article we ask: How the socio-economic position of the family is related to the school choice of the child? What is the role of socioeconomic status and educational level of parents in explaining the differences in attitudes towards the uniformity of comprehensive school system, and what, in turn, is the role of parental attitudes in explaining the school choice? To answer these questions we analyse large survey data collected in five biggest cities in Finland in spring 2012 ( $n=2$ 617). We conclude that school choice in Finland is particularly exercised by highly educated families whose children do well in school. Of the single factors the most predictive indicator of exercising the choice is the child's average of latest report card, but also variables indicating socio-economic background strongly predict the parental choice.

\footnotetext{
*Professor, Department of Education, University of Turku, Finland.

${ }^{\dagger}$ Researcher, Institute of Behavioral Sciences, University of Helsinki, Finland.

Researcher, Institute of Behavioral Sciences, University of Helsinki, Finland.
} 


\section{Introduction}

More than ten years, the international comparisons have highlighted the equality and quality of Finnish education system. Throughout the 2000s, PISAtest results have demonstrated that Finnish 15-year-olds score very high in math, science and reading. In Finland the percentage of pupils reaching only the lowest proficiency levels is very small, and, e.g., the weakest quintile of Finnish readers read better than the respective group of pupils in other countries. The variation of learning outcomes between schools is the lowest among the PISA-countries. Finally, the impact of pupils' socio-economic background on learning outcomes is much weaker than in most PISAcountries. (See e.g. OECD 2004; 2005; 2009; 2010; Sahlberg 2007.) Taken together, PISA-results indicate uncommon equality of the school system in Finland and the high and homogenous quality of schools. The Finnish comprehensive school has been praised as an example of an education system functioning commendably. As a result, the parents of school-aged children and, in fact, the whole adult population have been found to be very satisfied with the school system.

In Finland, schools' pupil bodies consisting of pupils living in the nearby area (school district) has been a central principle ever since the founding of the 'folk school' network in the 1890s. The comprehensive school system, introduced in Finland during the 1970s, integrated an entire age group into the nonselective and educationally homogeneous public schools for nine years. The most extensive organizational unity was achieved when streaming by ability was abolished in 1984. Streaming was found to exclude children (mainly boys) from lower-class families from the academic route at the postcompulsory education level. One of the central ideas of the comprehensive school system was to allocate all children to schools on the basis of residence. Permission to attend another than a catchment area school was granted to a pupil only for very grave reasons. The Finnish educational policy was very uniform in this respect, and until the mid-1990s children all across the country were placed in schools according to the same school district principle. (Seppänen 2003; 2006.)

Since the 1990s, administrative reforms, based on principles of decentralisation and deregulation, have reduced the direct national control and authorised Finnish municipalities to determine their own government and the ways by which to produce the services - like provision of basic education - of which they are in charge. As a result, local education authorities have developed distinctive policies and practices concerning local models of selection and admission with various opportunities to exercise parental choice. (Varjo \& Kalalahti 2011; Ylönen 2009.) The gradual introduction of educational diversity and parental choice has been a major deviation from the traditional idea of the comprehensive school system in Finland. Despite the changing education policy, diversification of schools and public ranking lists are commonly opposed.

The parents' role in the emergence of the school choice policy deserves 
special attention in that parents have been more like bystanders than initiating actors in the process. The school choice policy was not been implemented due to demand from the public. The national power elites (employer and business interest groups as well as the political right of the central administration officers) have brought about policy reforms and through them the school choice policy into national education system. The reforms have been legitimated by the recommendations of supranational elites and supranational organizations. (Rinne et al. 2004.) The national elites marketed the school choice policy as an opportunity to improve the national educational system according to "international trends" in the name of freedom and quality, and through "diversifying educational offering" and "improving individual possibilities for learning". (Seppänen 2006; Silvennoinen et al. 2012.).

Much of the educational reforming in Finland since the late 1980's has been adopted from transnational policy trends. Like Finnish educational sociologists say, Finland is like "a model pupil" and eager to comply with policy recommendations articulated, e.g., by OECD (Rinne, Kallo \& Hokka 2004; Rinne 2006). Numerous reforms throughout Europe have sought to dismantle centralised bureaucracies and replace them with devolved systems of schooling emphasising parental choice and competition between increasingly diversified types of schools. In decentralised operational environments, new education policy initiatives have been implemented and adapted in very different and even contradictory ways on the sub-national level. These changes in local-central relations have produced a shared repertoire of structural and relational changes including deregulation, decentralisation and devolution, along with marketization, choice and individualisation (Green et al. 1999; Ozga et al. 2011).

In the global perspective, it seems apparent that the implementation of the school choice policy in Finland follows, although not mechanically, a topdown model of educational political governance and power with the supranational and national elites as the highest level actors. At the regional and local level (in municipalities) the school choice policy has been marketed by the political parties advocating for the middle classes. In general, it can be said that groups with ample economic and cultural resources are the major advocators of the school choice policy. Besides the interest towards widening school choice, the capabilities to make use of the school choice are not evenly distributed among the parents. The families with plentiful resources are the most active and determined in the utilization of the liberated school choice. (Silvennoinen et al. 2012.) This tendency can be seen in the case of proliferation of "free schools" in Sweden, too (Bunar 2010). There is a whole lot of research approving that the changing admission and selection policies and emerging possibilities to exercise parental choice have been more beneficial to upper echelons than lower social classes (see e.g. Reay \& Ball 1997; Lauder et al. 1999; Reay \& Lucey 2000; Ball 2003).

A recent analysis from Sweden has clearly demonstrated how an admission reform abolishing residence-based admission rules increases 
segregation. The reform 'benefited those with the highest grades as new options became available and school district borders no longer limited their school choices. As expected, the grade-based admission system increased the sorting of students to schools according to their ability. Less expected was that this reform, which was supposed to reverse the effects of residential segregation on school segregation, actually increased segregation along all other observable dimensions, particularly along ethnic and socio-economic lines.' (Söderström \& Uusitalo 2010, 75.) All these changes were reasonably large.

Evidently, school choice is related to the family's resources, but also to values, attitudes and preferences of parents. The aim of the paper is to identify and analyse a range of variables indicating the socio-economic position of families and school choice strategies within the social and educational context of Finland. The associations between school choice and class position of families have been mostly examined by descriptive qualitative data, whereas fewer attempts have been made to disentangle and measure the various dimensions of socio-economic position (or "class position", if you wish) and school choice. Here, in order to separate the diverse dimensions, several socioeconomic indicators are examined concurrently using quantitative data.

This study contributes to the research on socio-economic patterning of school choice by examining simultaneously five dimensions of socio-economic position. Education, occupational status and income form a set of indicators that position families in the hierarchy of society. While all of these dimensions reflect family's positions in the class structure, they might also have specific explanatory power in explaining socially constructed educational preferences, as well as the variation in school choice activity. We might see them as an anchor of social structure, objectively viewed. As a key element of educational strategies, especially in relation to Finnish strong emphasis on equal educational opportunities and uniformity of schools, we examine also the relationship of parental attitudes towards uniformity of comprehensive school and school choice.

\section{Allocation of Pupils to Schools in Finland}

The highly uniform, standardised and top-down governed Finnish comprehensive school has changed significantly since the 1990's. Prior to the changes, it was commonly understood that the Ministry of education's task was to plan and administer the education system; however, since the 1990's its primary role has been the providing of goals and guiding frameworks. Consequently, municipalities have gained more power to determine their own affairs and decide the ways by which to produce the services - like the provision of basic education - of which they are in charge. (Simola et al. 2009.) According to Green, Wolf and Leney $(1999,91)$ the model of Finnish educational regulation shifted to emphasise local control and involve a "predominance of control at the level of elected local authority within a light 
framework of central regulation and with some school autonomy". This has allowed local education authorities to develop local models of admission and selection (with varying scope to exercise parental choice), the specialisation and diversification of schools, competition between schools and principles for the local allocation of resources. (Kalalahti \& Varjo 2012; Varjo \& Kalalahti 2011; Ylönen 2009; Seppänen 2006.)

The 1999 Basic Education Act (Law 628/1998) only obliges municipalities to assign to each child of elementary school age 'a neighbourhood school or some other appropriate place where education is given'. Simultaneously, the term "school district" was removed from the legislation. Nevertheless, the notion of a neighbourhood school means that children are obliged to go to a designated school that is defined in terms of proximity and local conditions. According to the law, municipalities are obliged to 'make pupils' travel to and from school as safe and short as possible in view of the habitation, the location of schools and other places of education, and public transportation' (Law 628/1998).

Simultaneous to the new mode of governance and more individualised interpretations of equality of opportunity have empowered municipalities to develop distinctive policies and practices in allocating the children to their neighbourhood schools in an equitable manner. Despite the different local arrangements, the interpretation of "neighbourhood school" is crucial comprehending the Finnish notion of the right to education. (Kalalahti \& Varjo 2012; Varjo \& Kalalahti 2011.)

The Basic Education Act (Law 628/1998) enabled parents to choose between schools on the grounds of their particular character and curriculum. Education providers and their comprehensive schools are still required to maintain a national core curriculum. However, within a given framework they are allowed to specialise in certain areas - i.e. to develop and express a distinctive character to meet the different demands of parents and the different aptitudes of students: 'If education is given according to a curriculum with special emphasis on one or several subjects, the admission of pupils may also be based on a test showing aptitude for said education. The selection criteria and the aptitude test shall be made known in advance.' (Law 628/1998)

As a result, educational diversity inside the traditionally homogeneous national curriculum has increased. Since the 1990s, national guidelines have been made more flexible and open to local variations. Municipalities, through their elected education boards, have been given powers to decide on the allocation of the hours for different subjects in all schools in their areas. Schools have started "taking profiles" (see Ylönen 2008), i.e. offering specialisation in particular subjects in the curriculum or placing emphasis on some more general themes (the environment or communication, for instance). These "classes with special emphasis" (painotetun opetuksen ryhmät) function as separate streams within regular municipal schools. They have more lessons (for instance in music, sports, science, languages or arts) than the National Core Curriculum requires. Importantly, the "neighbourhood school" principle 
doesn't apply to the classes with special emphasis - they commonly draw in students from the whole municipal area because of their particular emphasis. (Ylönen 2008; Seppänen 2006.)

In Finland's strictly comprehensive system, the classes with special emphasis are the principal way to exercise parental choice: they are essential for comprehending the Finnish notion of freedom of education.

\section{Research Design: Research Questions, Data, Measures, Methods}

In this paper we ask: How is the socio-economic position (indicated here by mother's education level, employer sector, income, and subjective estimation of one's own socio-economic standing) associated with the school choice of the pupil? What is the role of socio-economic position of the family in explaining differences in parents' attitudes towards the uniformity of comprehensive school system, and what, in turn, is the role of parental attitudes in explaining the school choice?

In the following, we analyse family survey data collected for the Parents and School Choice ${ }^{1}$ research project. The data were gathered by a survey questionnaire, conducted in five biggest cities in Finland in spring $2012^{2}$. The questionnaire was targeted at the parents of the sixth grade pupils who were just entering the secondary stage of comprehensive school. The number $(\mathrm{N})$ of respondents in the data is 2617 . The operationalization of questionnaire questions and key concepts are firmly grounded in the interviews conducted with more than 300 families earlier in the project. In this paper the attitudes towards the uniformity of comprehensive schools are measured by using six indicators, separately and as a sum score. The school choice is measured by the information (dichotomous variable) whether or not the child was attending school or class with special emphasis.

The socio-economic position of families is measured by three objective indicators: mother's education level, mother's income level and mother's employment sector ${ }^{3}$. We also aim at capturing the individuals' own estimation of the family's rank in societal hierarchies by measuring subjective socioeconomic position. In this we will use the measurement known as The MacArthur Scale of Subjective Social Status which has been developed to capture the common sense of social status across the SES indicators (in pictorial format, it presents "a social ladder" with ten rungs; Adler \& Stewart 2007). ${ }^{4}$ Previously subjective socio-economic status indicator has been used to

\footnotetext{
${ }^{1}$ Parents and School Choice - Family Strategies, Segregation and Local School Policies in Chilean and Finnish Basic Schooling, funded by Academy of Finland and Comisión Nacional de Investigación Científica y Tecnológica de Chile.

${ }^{2}$ The questionnaires were distributed by mail in Helsinki, Espoo, Vantaa, Turku, and Tampere, and the parents had the possibility to answer on paper or via e-form. The number of recipients was 12 032, the final response rate is $22 \%$.

${ }^{3}$ Our focus on mothers draws on previous studies that have highlighted the importance role of mothers in school choice processes (Seppänen 2006; Reay 1998).

${ }^{4}$ In the questionnaire there was a picture of a ladder, and text went as follows: 'Imagine this
} 
measure person's own evaluation of his or her social position in relation, for example, to health status (Singh-Manoux et al. 2005) and attitudes towards school (Kalalahti et al. 2011). The subjective socio-economic status can be seen as a separate dimension of person's objective socio-economic position (measured by theoretically justified variables), as well as an indicator of subjective class identification.

The variables used in the following analyses are:

Dependents

1. School choice (attending school / class with special emphasis)

2. Attitudes towards the uniformity of comprehensive schools Independents

1. Mother's education level

2. Mother's income

3. Mother's employment sector

4. Subjective socio-economic position

5. The average of child's latest report card

6. Attitudes towards the uniformity of comprehensive schools

The sum score of attitudes towards the uniformity of comprehensive schools will be analysed with reliability analysis. Each response to the statements varies from one to six (1-6), where one (1) represents disagreement and five (5) agreement with the opinion and six (6) represented unwillingness to answer (excluded from the analyses). The scales of three questions are transposed to have the same scale. After reduction, the total score of items is six and the sum score will be formed by mean scores. The score is sufficiently normally distributed (mean $=3.19$, Std. deviation $=.73$ ) and has sufficiently internal consistency (Cronbach's alpha coefficient $=0.70$ ). It will be used both as constant variable and categorized variable ranging from one to three (1-3), one (1) representing disagreement and three (3) representing agreement with the uniformity of comprehensive schools.

Each socio-economic indicator will be first cross-tabulated with all six attitude variables and the school choice variable. The measurement of school achievement is also included in the cross-tabulation. The relationship between attitudes and socio-economic variables is tested by the Pearson chi-square test $(p<0.05)$. All of them will be included in a multivariate analysis. Logistic regression analysis will be used to examine the associations of attitudes and socio-economic indicators with school choice. Odds ratios (OR) for school choice will be calculated so that the lowest education level, the lowest

ladder representing the Finnish society. At the top of the ladder are the most well-off people, with the most money, best education and jobs who the most people respect. At the lowest rung of the ladder are the worst-off people, with the smallest amount of money, not much of an education or a job, or they have a job that is not respected. Where would you place yourself? Check the step that best represents your position on the ladder.' 
educational achievement, the private sector employment, mid income level and emphasis towards the uniformity of comprehensive schools are selected as the reference category. The variable of subjective socio-economic position is used as a scale variable.

\section{Results}

Our analysis confirms that, like in countries with traditionally wide classbased educational inequalities, also in Finland the school choice is strongly connected to social background of the pupil (Table 1). School choice is a social practice, exercised actively especially among high income, highly educated families, who subjectively rank themselves high in the society and whose children do well in school. One third of the children from lowest income group (mother's income less than 20.000 Euros per year) attend school or class with special emphasis, compared to 40 per cent of children from families with higher income (mother's income more than 50.000 per year).

Table 1. School Choice (Attending School/class with Special Emphasis) by Socio-Economic Indicators $(\%)(n=2617)$

\begin{tabular}{|c|c|c|c|}
\hline & & $\%$ & $\mathrm{~N}$ \\
\hline \multirow{3}{*}{$\begin{array}{c}\text { Mother's income } \\
<0.001\end{array}$} & Under 20000 & 31 & 372 \\
\hline & $20000-49999$ & 30 & 1546 \\
\hline & 50000 or more & 40 & 501 \\
\hline \multirow{5}{*}{$\begin{array}{l}\text { Mother's education } \\
\mathbf{p}<0.001\end{array}$} & $\begin{array}{l}\text { Comprehensive/upper secondary } \\
\text { school/vocational school }\end{array}$ & 22 & 606 \\
\hline & & & \\
\hline & Upper vocational & 29 & 690 \\
\hline & Polytechnic & 30 & 376 \\
\hline & University & 42 & 888 \\
\hline \multirow{2}{*}{$\begin{array}{c}\text { Mother's employer } \\
\text { p>0.05 }\end{array}$} & Public sector & 32 & 1256 \\
\hline & Private or other employer & 32 & 1140 \\
\hline \multirow{5}{*}{$\begin{array}{c}\text { Subjective socio- } \\
\text { economic status } p<0.001\end{array}$} & $1-4$ & 22 & 186 \\
\hline & $5-6$ & 28 & 644 \\
\hline & 7 & 30 & 654 \\
\hline & 8 & 36 & 691 \\
\hline & $9-10$ & 43 & 312 \\
\hline \multirow{4}{*}{$\begin{array}{c}\text { The average of child's } \\
\text { latest report card } \\
\mathbf{p}<0.001\end{array}$} & $9-10$ & 46 & 563 \\
\hline & $8-8,9$ & 32 & 1316 \\
\hline & $7-7,9$ & 20 & 472 \\
\hline & $<6,9$ & 9 & 43 \\
\hline
\end{tabular}


Children from highly educated families (mother university level educated) attend more often (42\%) to school/class with a special emphasis than children from other education level groups. The same pattern is also evident in the case of subjective socio-economic position: the higher the self-estimated position in societal ladder, the higher the share of the children attending to school/class with a special emphasis. The Finnish version of school choice is not only constructed on the socio-economic status of the family but also on the school performance of the child. Children attending the school/class with a special emphasis have much better school grades than their "non-selected" peers.

The variation of attitudes towards the uniformity of comprehensive schools and the association of socio-economic indicators with these attitudes is cross-tabulated in Table 2. Mother's education level and employer sector are the most significant in explaining the variation of single measurements, when analysing responses agreeing or strongly agreeing with the statements. Most university level mothers $(61 \%)$ think that increasing the options in choosing schools cause differentiation of learning outcomes whereas less than half $(43 \%)$ of mothers with the lowest education level agree with the statement. Therefore, it seems comprehensible that the university level educated mothers do not endorse specialisation of schools ('Comprehensive schools must differentiate themselves from each other with specialisations') or widening of parental choice ('Parents should be offered more possibilities to pick the secondary school they want for their child') as much as the lower education level mothers do.

Besides being more in favour for parental choice, 38 per cent of the low educated mothers call for public ranking lists ('The learning outcomes of secondary schools should be made public, in order to give parents concrete information when making school choices') compared to total 33 per cent. This may be interpreted as suggesting that high education level and concern for the segregation prevent from demanding specialisations, parental choice and ranking lists. This might also indicate that mothers with lower education level feel that they need valid and external information in order to perceive the relevant quality differences between schools (and to sort out the "good" schools from the "mediocre" or the "bad" ones). 
Table 2. Parental Attitudes towards the Uniformity of Comprehensive Schools (Agreeing or Agreeing Strongly with the Statements) by Socio-Economic Factors $(\%)(n=2617)$

\begin{tabular}{|c|c|c|c|c|c|c|c|}
\hline & & 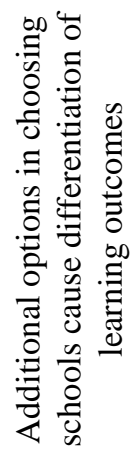 & 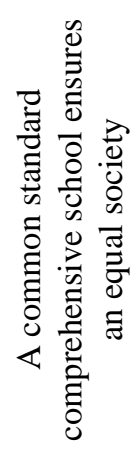 & 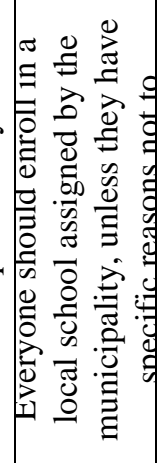 & 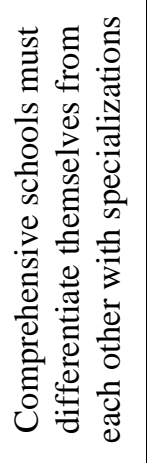 & 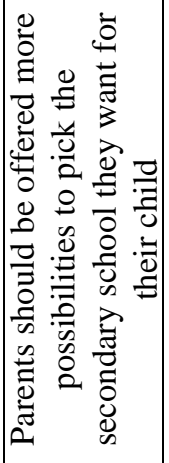 & 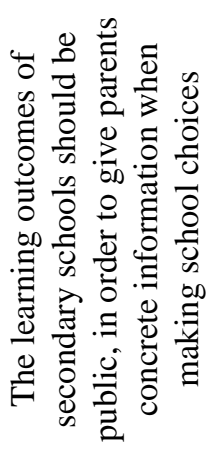 \\
\hline \multirow{5}{*}{$\begin{array}{l}\text { Mother's } \\
\text { education }\end{array}$} & $\begin{array}{l}\text { Comprehensive/ upper } \\
\text { secondary school/ } \\
\text { vocational school }\end{array}$ & 43 & 64 & 31 & 32 & 49 & 38 \\
\hline & Upper vocational & 52 & 60 & 30 & 27 & 43 & 31 \\
\hline & Polytechnic & 56 & 57 & 28 & 31 & 46 & 34 \\
\hline & University & 61 & 62 & 31 & 22 & 36 & 32 \\
\hline & & $\mathrm{p}=0.001$ & $\mathrm{p}<0.05$ & $p>0.05$ & $\mathrm{p}<0.001$ & $\mathrm{p}<0.001$ & $\mathrm{p}<0.001$ \\
\hline \multirow{4}{*}{$\begin{array}{l}\text { Mother's } \\
\text { income } €\end{array}$} & Under 20000 & 46 & 63 & 32 & 29 & 47 & 34 \\
\hline & $20000-50000$ & 55 & 61 & 32 & 27 & 40 & 31 \\
\hline & 50000 or more & 58 & 59 & 27 & 26 & 43 & 39 \\
\hline & & $\mathrm{p}>0.05$ & $\mathrm{p}<0.05$ & $\mathrm{p}>0.05$ & $\mathrm{p}<0.05$ & $\mathrm{p}>0.05$ & $\mathrm{p}<0.001$ \\
\hline \multirow{3}{*}{$\begin{array}{l}\text { Mother's } \\
\text { employer }\end{array}$} & Public sector & 56 & 64 & 33 & 24 & 39 & 32 \\
\hline & Private or other employer & 52 & 57 & 28 & 30 & 45 & 35 \\
\hline & & $\mathrm{p}<0.01$ & $\mathrm{p}<0.01$ & $\mathrm{p}<0.01$ & $\mathrm{p}<0.001$ & $\mathrm{p}<0.001$ & $\mathrm{p}<0.001$ \\
\hline \multirow{6}{*}{$\begin{array}{l}\text { Subjective } \\
\text { socio- } \\
\text { economic } \\
\text { status }\end{array}$} & $1-4$ & 40 & 60 & 30 & 33 & 48 & 35 \\
\hline & $5-6$ & 51 & 62 & 29 & 27 & 45 & 30 \\
\hline & 7 & 58 & 65 & 33 & 27 & 41 & 34 \\
\hline & 8 & 55 & 60 & 30 & 24 & 40 & 33 \\
\hline & $9-10$ & 59 & 58 & 30 & 30 & 39 & 40 \\
\hline & & $\mathrm{p}<0.01$ & $\mathrm{p}>0.05$ & $\mathrm{p}<0.05$ & $\mathrm{p}<0.01$ & $p>0.05$ & $\mathrm{p}>0.05$ \\
\hline Total & & 54 & 61 & 30 & 27 & 42 & 33 \\
\hline
\end{tabular}

One of the basic principles of Finnish comprehensive school system has been to ensure equality of opportunity that, in turn, will foster societal equality. Therefore, we included the statement 'a common standard comprehensive school ensures an equal society' to our questionnaire. It seems that the mothers employed in the public sector endorse this principle more strongly than mothers employed in private sector. In accordance to this, public sector employees are more in favour of the "neighbourhood school" principle ('Everyone should enrol in a local school assigned by the municipality, unless they have specific reasons not to'), and do not favour school specialisation and 
wider parental school choice.

Mother's socio-economic position and attitudes are intertwined in various and complex ways. The lowest income group emphasises, on one hand, the common standard school as a guarantee of equal society, but on the other, they call for more school specialisations. Curiously, mothers both in the lowest and the highest income groups are less negative towards public ranking lists, whereas mothers in the mid income group are more often against them. The same kind of slight "middle class resistance" can be found when analysing the attitudes by the subjective socio-economic status: contrary to the stance of the highest and the lowest subjective socio-economic groups, the mothers in the middle rungs of the social ladder do not feel need for increasing the specialisation of schools as often.

Finally we move on to the results of the logistic regression analysis (Table $3)$.

Table 3. Associations between Socio-Economic Indicators and School Choice in Logistic Regression Model (Odds Ratios and their $95 \%$ Confidence Intervals) $(n=2617)$

95\% C.I.for $\operatorname{EXP}(\mathrm{B})$

\begin{tabular}{|c|c|c|c|c|c|}
\hline & & \multirow{2}{*}{ Oddsratio } & \\
\hline & & & Sig. ${ }^{1}$ & Lower & Upper \\
\hline \multirow{4}{*}{$\begin{array}{l}\text { Mother's } \\
\text { education }\end{array}$} & $\begin{array}{l}\text { Comprehensive/upper } \\
\text { secondary school/ } \\
\text { vocational school }\end{array}$ & 1,00 & & & \\
\hline & Upper vocational & 1,42 & $*$ & 1,04 & 1,94 \\
\hline & Polytechnic & 1,35 & & 0,95 & 1,91 \\
\hline & University & 1,99 & $* * *$ & 1,44 & 2,75 \\
\hline \multirow{2}{*}{$\begin{array}{l}\text { Mother's } \\
\text { employer }\end{array}$} & Private or other employer & 1,00 & & & \\
\hline & Public sector & 1,09 & & 0,90 & 1,34 \\
\hline \multirow{3}{*}{$\begin{array}{c}\text { Mother's income } \\
€\end{array}$} & $20000-49999$ & 1,00 & & & \\
\hline & Under 20000 & 1,48 & $*$ & 1,08 & 2,04 \\
\hline & 50000 or more & 0,97 & & 0,75 & 1,26 \\
\hline \multirow{3}{*}{$\begin{array}{l}\text { The average of } \\
\text { child's } \\
\text { latest report card }\end{array}$} & $<7,9$ & 1,00 & & & \\
\hline & $8-8,9$ & 2,10 & $* * *$ & 1,57 & 2,81 \\
\hline & $9-10$ & 3,28 & $* * *$ & 2,37 & 4,55 \\
\hline \multirow{3}{*}{$\begin{array}{l}\text { Attitudes towards } \\
\text { the uniformity of } \\
\text { comprehensive } \\
\text { schools }\end{array}$} & More important & 1,00 & & & \\
\hline & Neutral & 1,78 & $* * *$ & 1,43 & 2,22 \\
\hline & Less important & 2,90 & $* * *$ & 2,15 & 3,90 \\
\hline \multicolumn{2}{|c|}{$\begin{array}{l}\text { Subjective socio- } \\
\text { economic status }\end{array}$} & 1,09 & $*$ & 1,01 & 1,18 \\
\hline
\end{tabular}

When the socio-economic indicators and the sum score of attitudes towards the uniformity of comprehensive schools are included in the model 
together, the association between mother's education and school choice is still evident. Based on odds ratios, mothers with university level education are the keenest to exercise parental choice when contrasted to the lower education level mothers (odds ratio 2). When adjusted with other socio-economic indicators, curiously enough, it seems that the lowest income group attend most likely to the school/class with a special emphasis. After the education level is taken into account, the school choice is not associated with high or mid income but the lowest income group. This needs further analysis. One explanation could be that maybe these are highly educated families where fathers are highly paid and mothers stay at home despite that they have university education.

While all the objective socio-economic indicators are included in the model, also the indicator of the subjective socio-economic status becomes significant. This indicates that school choice has a dimension beyond objective socio-economic indicators and intertwines with the subjective understanding of social class. Besides, the attitude measurement of the uniformity of comprehensive schools has a strong significance to the school choice. Parents that perceive the uniformity of comprehensive school less important, attend most likely to the school/class with special emphasis (odds ratio 2.9). It is yet noteworthy that the most predictive indicator (greatest odds ratios, systematic associations and strongest significance) of school choice is the average of the latest report card of the child.

\section{Conclusions}

Widely known for its high quality and relative equal learning outcomes the Finnish comprehensive school system made a major turn in the mid 1990's when free school choice was introduced and the education providers were allowed to let parents to pick and choose the most desirable and suitable school for their children irrespective of the place of residence. The long-standing system of school districts was abolished, and schools were encouraged to differentiate and to specialize in their own areas of strength. However, numerous studies in several countries had verified the unwanted consequences of the new school choice policy (e.g. Adler et al. 1989; Gewirtz et al. 1995; Woods et al. 1998; Lauder et al. 1999; see Silvennoinen et al. 2012). The most talked about issue concerning the new policy in Finland has been the assumed segregation of schools by social background of the pupils and, consequently, widening differences in learning outcomes between "good" and "bad" schools.

School choice in Finland is particularly exercised by highly educated families who subjectively rank themselves high in society and whose children do well in school. Of single factors the most predictive indicator (greatest odds ratios, systematic associations and strongest significance) of school choice is the child's average of latest report card, but also variables indicating socioeconomic background strongly predict the parental choice.

The differences on educational strategies are built on the social class of families. Highly educated families are more aware of quality differences 
between schools and more willing to use their right to choose school for their child (Seppänen 2006). Working class families more often lack the capabilities or the confidence to form an active education strategy in school choice (Reay \& Ball 1997; Lauder et al. 1999). Better-off families are more active in making individual school choices, i.e. more likely to opt out "neighbourhood school" and apply to "emphasised class" with specialisation in one or more subjects, while choices are sporadic and considered to be less important issue among working class and lower class families. Middle classes make their choices efficiently by using the emphasised teaching as a mechanism of distinction. Highly educated parents seem to be well informed of the differences between schools due to belonging to appropriate social networks (possessing social capital). But because the publishing of ranking lists based on learning outcomes are banned in Finland, the lower classes are left to make their choices based on vague and rough information on school reputations.

School choice and attitudes towards the uniformity of comprehensive schools is associated with structural and material as well as subjective dimensions of socio-economic position. As our analysis indicates, the middle classes are most contented with the uniformity of the comprehensive school system. They are also aware of the potential consequences of the differentiation of schools on educational equality. Despite the fact that highly educated families are aware of negative outcomes of specialisation of the schools, they exercise parental choice most actively. When seeing the education as a field in Bourdieusian sense especially the difference between the relative positions of social classes becomes apparent (see Bourdieu 1979; Bourdieu \& Wacquant 1992). If you have the right capitals (Bourdieu 1986) and an appropriate habitus (Bourdieu 2005) for building a successful school career it would be against your individual interests not to take part in the game in an environment where you think all your peers, i.e. your competitors, try to maximise the profits to be gained in the game. Actually, it seems like especially the middle class families are "forced" to choose, once the free school choice system is introduced.

The new opportunities for making distinction may very well work for a certain subset of pupils, but in the long run it comes at the expense of equal quality of schools and equality of learning opportunities.

\section{References}

Adler, M., Petch, A. \& Tweedie, J. (1989). Parental Choice and Educational Policy. Edinburgh: Edinburgh University Press.

Adler, N. \& Stewart J. (2007). The MacArthur Scale of Subjective Social Status. http://www.macses.ucsf.edu/research/psychosocial/subjective.php

Ball, S. J. (2003). Class Strategies and The Education Market: the middle classes and social advantage. London: Routledge Falmer.

Bourdieu, P. (1979). La Distinction. Critique sociale du jugement. Éditions de Minuit, coll. Le sens commun. 
Bourdieu, P. (1986). The forms of capital. In J. G. Richardsson (ed.) Handbook of theory and research for the sociology of education. New York: Greenwood press, 241-258.

Bourdieu, P. (2005). Habitus. In J. Hiller and E. Rooksby (eds) Habitus: A Sense of Place. Aldershot: Ashgate Publishing, 43-49.

Bourdieu, P. \& Wacquant, L.J.D. (1992). An Invitation to Reflexive Sociology. Cambridge: Polity Press.

Bunar, N. (2010). Choosing for quality or inequality: current perspectives on the implementation of school choice policy in Sweden. Journal of Education Policy, 25(1), 1-18.

Gewirtz, S., Ball, S.J. \& Bowe, R. (1995). Markets, Choice and Equity in Education. Buckingham: Open University Press.

Green, A., Wolf, A. \& Leney, T. (1999). Convergence and Divergence in European Education and Training Systems. Institute of Education. University of London.

Kalalahti, M., Karvonen, S. \& Rahkonen, O (2011). Social hierarchies and positive attitudes towards school with Finnish secondary school students. The Journal of the Westermarck Society, Sosiologia, 48(3), 221-237. [In Finnish]

Kalalahti, M. \& Varjo, J. (2012). Equality and justice in admission and selection to basic education. Kasvatus \& Aika, 6(1), 39-55. [In Finnish]

Lauder, H., Hughes, D., Watson, S., Waslander, S., Thrupp, M., Strathdee, R., Simiyu, I., Dupuis, A., McGlinn, J. \& Hamlin, J. (1999). Trading in Futures: Why Markets in Education Don 't Work. Buckingham: Open University Press.

OECD (2004). Learning for Tomorrow's World - First Results from PISA 2003. Paris: OECD.

OECD (2005). School Factors Related to Quality and Equity. Results from PISA 2000. Paris: OECD.

OECD (2009). Equally Prepared for Life? Paris: OECD.

OECD (2010) What Students Know and Can Do: Student Performance in Reading, Mathematics and Science. PISA 2009 Results. Paris: OECD.

Ozga, J., Dahler-Larsen, P., Segerholm, C. \& Simola, H. (eds.) (2011). Fabricating quality in education. Data and governance in Europe. London: Routledge.

Reay, D. \& Ball S. J. (1997). 'Spoilt for Choice': The working classes and educational markets. Oxford Review of Education, 23(1), 89-111.

Reay, D., Crozier, G., James, D., Hollingworth, S., Williams, K., Jamieson, F. \& Beedell, P. (2008). Re-invigorating democracy? White middle class identies and comprehensive schooling. The Sociological Review, 56(2), 238-255.

Reay, D. \& Lucey, H. (2000). Children, School Choice and Social Differences. Educational Studies, 26(1), 83-100.

Rinne, R., Kallo, J. \& Hokka, S. (2004) Too Eager to Comply? OECD Education Policies and the Finnish Response. European Educational Research Journal, $3(2), 454-485$.

Rinne, R. (2006). Like A Model Pupil? Globalisation, Finnish Educational Policies and Pressure from Supranational Organizations. In J. Kallo \& R. Rinne (eds) Supranational Regimes and National Education Policies - Encountering Challenge. Research in Educational Sciences 24. Turku: Finnish Educational Research Association, 183-216.

Sahlberg, P. (2007). Education policies for raising student learning: the Finnish approach. Journal of Education Policy, 22(2), 147-171.

Seppänen, P. (2003). Patterns of 'public-school markets' in the Finnish comprehensive school from a comparative perspective. Journal of Education Policy 18(5): 513531 . 
Seppänen, P. (2006). School-Choice Policy in Comprehensive Schooling - School markets of Finnish cities in the international perspective. Research in Educational Sciences 26. Turku: Finnish Educational Research Association. [In Finnish]

Silvennoinen, H., Seppänen, P., Rinne, R. \& Simola, H. (2012) National and Local Realization of Supranational Education Policy: The Case of School Choice. The Finnish Journal of Education, Kasvatus, 43(5), 502-518. [In Finnish]

Simola, H., Rinne, R., Varjo, J., Kauko, J. \& Pitkänen, H. (2009). Quality Assurance and Evaluation (QAE) in Finnish Compulsory Schooling: A National Model or Just Unintended Effects of Radical Decentralisation? Journal of Education Policy, 24(2), 163-178.

Singh-Manoux, A. \& Marmot, M.G. \& Adler, N.E. (2005). Does Subjective Social Status Predict Health and Change in Health Status Better Than Objective Status? Psychosomatic Medicine, 67(6), 855-861.

Söderström, M. \& Uusitalo, R. (2010).School Choice and Segregation: Evidence from an Admission Reform. Scandinavian Journal of Economics, 112(1) 55-76.

The Basic Education Act, Law 628/1998.

Varjo, J. \& Kalalahti, M. (2011). Constructing the institutional space for parental school choice. Yhdyskuntasuunnittelu, 49(4), 8-25. [In Finnish]

Varjo, J., Kalalahti, M. \& Silvennoinen, H. (submitted). Families, school choice and democratic iterations on the Right to Education and Freedom of Education in Finnish municipalities. Journal of School Choice.

Välijärvi, J., Kupari, P., Linnakylä, P., Reinikainen, P., Sulkunen, S., Törnroos, J., Arffman, I. (2007). The Finnish Success in Pisa - And Some Reasons Behind It: Pisa 2003. Jyväskylä: University of Jyväskylä.

Ylönen, A. (2009). Specialisation within the Finnish comprehensive school system. Reasons and outcomes for equity and equality of opportunity. VDM Verlag Dr. Müller, Saarbrücken. 
